\title{
KADDOUR EL CONDUCTOR. \\ ESCENA DRAMÁTICA DE LA OBRA LOS DICHOS \\ DE ABDELKADER ALLOULA
}

\author{
NAIMA BENAICHA ZIANI \\ Universidad de Alicante
}

\section{NOTA INTRODUCTORIA}

El papel de la Halqa y de el goual en el teatro argelino, igual que en la Commedia dell'arte, son omnipresentes en todas las plazas públicas de las diferentes ciudades de Argelia. Tradicionalmente es el estilo más popular para expresar las turbaciones sociales. A través de esta forma, Alloula consiguió transmitir ideas imposibles de expresar en la vida de todos los días. Lo hacía para los que no tenían la posibilidad de escribir, de decir o de hacer.

El personaje que aquí presentamos desarrolla su narrativa en torno a los dos elementos que Abdelkader Alloula consiguió enraizar para siempre en el teatro argelino. Hoy en día hablar de teatro argelino es hacer referencia a los conceptos de halqa y goual y, por ende, a Abdelkader Alloula.

Kaddour es el chófer, el trabajador fiel, honesto y leal, padre de cinco hijos, es un personaje de la obra el Agoual. Viene decidido a presentar su renuncia a su puesto de trabajo. Un puesto que, arduamente, consiguió en 1962, justo después de la independencia de Argelia. Durante la colonia francesa y, mientras luchaba por la libertad y la dignidad, Kaddour soñaba con un trabajo decente en una empresa estatal.

Nos habla de corrupción, de abuso de bienes sociales, de la distancia que separa irremediablemente la gente del poder. Lo hace sin cólera y sin odio, gracias a una voz liberadora, una palabra que anhela la verdad, subrayada por la música que acompaña la emoción, en un eco fiel a las palabras y a los sentimientos. La balqa es el escenario óptimo para tal fin. 
Kaddour, el conductor

Señor Naser, tome, lea esta carta... es una carta para Usted, Señor Director...

Lea... léala...Sí, es mi dimisión

Pido que me eche ahora... quiero dimitir ahora mismo...

No hace falta que hable Señor Naser, Sr Director... hoy, hablo yo...

llevo callado, sigiloso casi quince años, pero hoy hablaré...

deseo que me escuche bien y no intente cortarme...

se estará preguntando y diciendo ¿Qué le pasa a Kaddour, se ha vuelto loco?... ¿No estará borracho?... ¿¿no será un malentendido?...

Pues, no... Kaddour hoy ajustó cuentas consigo mismo y está decidido...

Kaddour hoy decidió actuar, después de un largo y profundo análisis...

Kaddour hoy rompió el hilo que le unía al Sr. Naser, lo rompió intencionadamente...

Esta carta es administrativa y no manifiesta las verdaderas causas, es por eso que se la entrego yo mismo en mano...

es por eso que he venido expresamente...

entonces, si me extiendo no intente interrumpirme o pararme...

es más, no le dejaré hablar...

y cuando me haya marchado de aquí, no intente buscarme, Sr. Naser. 
A partir de hoy se separan nuestros caminos... y puede que lo hagan para siempre... dimito de la empresa, Sr. Naser, porque el camino que hemos escogido los dos juntos hasta ahora no nos lleva a ninguna parte...

cuando digo el camino que hemos escogido, a decir verdad, yo aquí ni pincho ni corto...

pues eso, el camino que ha cogido usted y yo detrás de usted no sirve para nada...

me he cansado mientras me lo recorría y me harté de mí mismo...

me harté de mí mismo y de usted más que de nada...

entonces hoy vengo para dimitir de esta empresa nacional y a la vez de la relación de amistad que nos unía...

Kaddour el conductor, hoy se marcha de la empresa nacional y hoy mismo sepultará...

sí, enterrará definitivamente la amistad que le unió durante dieciocho años al Sr. Naser, el Director...

no es una gran pérdida ni la empresa perdió un directivo... no soy más que un conductor, ¿a quién le importará?...

no importa... Kaddour, el conductor, está contento hoy...

Kaddour, el conductor, el examigo del director, está feliz hoy...

Kaddour está hoy como si hubiera atravesado mares, montañas y ríos...

Kaddour, el energúmeno, está hoy en armonía consigo mismo: encontró la paz, la sencillez, la humildad de antaño, las virtudes con las que antes vivía... 